\title{
Defective Bacteriophage PBSH in Bacillus subtilis
}

\author{
I. Induction, Purification, and Physical Properties of the Bacteriophage and \\ Its Deoxyribonucleic Acid \\ MARTIN HAAS AND HIROSHI YOSHIKAWA \\ Space Sciences Laboratory, University of California, Berkeley, California 94720
}

Received for publication 27 September 1968

\begin{abstract}
PBSH, a defective phage of Bacillus subtilis strain 168, is described. Conditions are given for optimal induction of the prophage with mitomycin C. After a latent period of $90 \mathrm{~min}$, cells were lysed and phage-like particles were released with a burst size of approximately 100 to 400 phage per bacterium. Since no known host supports phage replication after infection, burst size was determined by electron microscope count. Purification procedures and criteria for purity are described. The molecular weight of deoxyribonucleic acid (DNA) extracted from PBSH was estimated by length measurement and sedimentation. No circular DNA molecules were found by either technique. PBSH DNA molecules are linear, double-stranded, and of homogeneous molecular weight, about $12 \times 10^{6}$ daltons. There is no evidence for single-strand breaks. The majority of PBSH DNA molecules show a sedimentation behavior dependent on ionic strength. It is inferred that most of the DNA molecules are less hydrodynamically rigid than native DNA having a similar average base composition and molecular weight. Possible reasons for the sedimentation behavior are discussed.
\end{abstract}

Phage-like particles have been reported in lysates of many bacterial species. Some of these particles have properties similar to those of bacteriocins (35). Bradley (5) reported the isolation of killer particles from Bacillus and Acetobacter. Bradley and Dewar (7) reported similar particles in Escherichia coli, Pseudomonas aeruginosa, and Listeria monocytogenes (see also reference 6). Hideya et al. (17) and Frampton and Brinkley (11) showed the existence of phage-like particles in $E$. coli. Tikhonenko and Bespalova (39), Eiserling (Ph.D. Thesis, Univ. of California, Los Angeles, 1964), Stickler et al. (33), Seaman et al. (32), and Ionesco et al. (20) have shown the existence and some properties of phage-like particles from $B$. mycoides, $B$. subtilis, $B$. licheniformis, and $B$. natto, respectively. The existence of these particles is thus quite common in both gram-positive and gramnegative bacteria. Particles produced by various strains of $B$. subtilis have been reported to have killing activity (PBSX, reference $32 ; \pi$ and $\mu$, reference 20), transducing properties (PBSX), or no transducing properties $(\pi$ and $\mu$ ). Attempts to cure the host cells or to find a host on which these phages will propagate have been unsuccessful.

The present study was started when a phagelike particle, which we called PBSH, was acci- dentally induced during experiments on thymineless germination of $\boldsymbol{B}$. subtilis spores, strain MY2Y1U5, a leucine, indole, thymine auxotroph (42). In this report, we present conditions for induction of the prophage, electron microscopy of the lysate, and purification of the wholephage particles and phage tails. In addition, physical properties of the phage and of phage deoxyribonucleic acid (DNA) are described. A preliminary report of this (16) and the accompanying paper (15) also describe the biological properties of phage PBSH.

\section{MATERIALS AND METHODS}

Bacterial strains. Strain MY2Y1U5, leucine- ${ }^{-}\left(\mathrm{leu}^{-}\right)$, indole ${ }^{-}\left(\right.$ind $\left.^{-}\right)$, thymine ${ }^{-}\left(\right.$thy $\left.^{-}\right)$, was used for induction of phage PBSH throughout. This strain is also designated 168LTT and is more sensitive to mitomycin C (MC) and ultraviolet (UV) irradiation than its parental strain, 168. A $0.1-\mu \mathrm{g}$ amount of MC per $\mathrm{ml}$ completely inhibited growth on minimal plates. Induction procedures were tested on other strains to compare induction efficiency. The following strains were used: $\mathrm{W} 23 \mathrm{LH}$, a revertant to thymine prototrophy of a leucine-histidine-thymine-requiring W23 strain, and strain W168, a strain transformed to prototrophy from the original indole-requiring strain Marburg. The MC-resistant strain, 168LTT-CA1, was isolated during an attempt to cure strain 168LTT of PBSH. Strain 168LTT was treated for 15 min with 3 
$\mu \mathrm{g}$ of MC pcr $\mathrm{m}_{\mathrm{l}}$ in Penassay Eroth in the presence of $20 \mu \mathrm{g}$ of proflavine per $\mathrm{ml}$. After resuspension, the culture was grown overnight in Penassay Broth (Antibiotic Medium 3, Difco) in the presence of $20 \mu \mathrm{g}$ of proflavine per $\mathrm{ml}$ and survivors were plated on Brain Heart Infusion (Difco). Strain CAl showed very smooth colony morphology and was thought to be cured of phage. It later proved to be MC-resistant at a level of $1.5 \mu \mathrm{g} / \mathrm{ml}$ or more (on minimal plates) but produced PBSH when irradiated with UV to a survival of $15 \%$ in medium CG (42).

Media. One liter of low phosphate $(0.002 \mathrm{M})$ Penassay Broth contained $1.5 \mathrm{~g}$ of Beef Extract (Difco), $5 \mathrm{~g}$ of peptone, $1 \mathrm{~g}$ of dextrose (Difco), $3.5 \mathrm{~g}$ of $\mathrm{NaCl}, 20 \mathrm{mg}$ of L-leucine, $20 \mathrm{mg}$ of L-tryptophan, 3 to $20 \mathrm{mg}$ of thymidine or ${ }^{3} \mathrm{H}$-thymidine, and $12.1 \mathrm{~g}$ of tris(hydroxymethyl)aminomethane (Tris), at $p \mathrm{H}$ 7.1. This medium was used to prepare ${ }^{32} \mathrm{P}$-labeled phage and ${ }^{3} \mathrm{H}$-labeled phage. For nonlabeled phage, one-half of the normal concentration of Penassay Broth was regularly used. Synthetic medium C+GB was used to obtain 5-bromodeoxyuridine (5-BUdR)substituted phage or to study thymineless phage development or thymine turnover. Medium $\mathrm{C}+\mathrm{GB}$ contained $0.002 \mathrm{M}$ phosphate; 1 liter contained $12.1 \mathrm{~g}$ of Tris, $1.0 \mathrm{~g}$ of trisodium citrate $2 \mathrm{H}_{2} \mathrm{O}, 140 \mathrm{mg}$ of $\mathrm{K}_{2} \mathrm{HPO}_{4}, 60 \mathrm{mg}$ of $\mathrm{KH}_{2} \mathrm{PO}_{4}, 2 \mathrm{~g}$ of $\left(\mathrm{NH}_{4}\right)_{2} \mathrm{SO}_{4}$, $0.2 \mathrm{~g}$ of $\mathrm{MgSO}_{4}, 100 \mathrm{mg}$ of L-glutamate, $500 \mathrm{mg}$ of casein hydrolysate, $50 \mathrm{mg}$ of L-tryptophan, $20 \mathrm{mg}$ each of adenine, cytosine, guanosine, and uracil, and thymidine when required. Generation time at $37 \mathrm{C}$ with vigorous aeration in this medium was approximately $30 \mathrm{~min}$, as compared with approximately 20 min in Penassay Broth.

Induction and purification of phage PBSH. The basic procedure for induction was as follows. An overnight culture made from a fresh slant was diluted 200 times in prewarmed Penassay Broth or C+GB. A 100- to $300-\mathrm{ml}$ amount was vigorously shaken in a 1.5 - to 3-liter growth flask or Erlenmeyer flask at $37 \mathrm{C}$. Cells were grown to a concentration of $1.5 \times 10^{7}$ per ml, ( 23 Klett units at $670 \mathrm{~nm}$ ), $4 \mu \mathrm{g}$ of MC (Sigma) per $\mathrm{ml}$ was added, and shaking was continued for $15 \mathrm{~min}$.

Cells were resuspended in an equal volume of prewarmed medium after rapid filtration through a 0.45- $\mu \mathrm{m}$ filter (Millipore Corp., Bedford, Mass.) or after rapid centrifugation in a centrifuge at $37 \mathrm{C}$. Lysis occurred within 90 min and was very abrupt.

The lysate was concentrated by centrifugation for $60 \mathrm{~min}$ at $80,000 \times g$ (Spinco no. 30 rotor, 30,000 $\mathrm{rev} / \mathrm{min}$ ) in polycarbonate screw-cap tubes (Nalge Co., Inc., Rochester, N.Y.). The pellet was dissolved by keeping it covered, in the cold, with a few milliliters of $1 \%$ ammonium acetate with $0.01 \mathrm{M} \mathrm{MgCl}_{2}$ (AAM). This solution was used for phage resuspension, because our only assay method at the outset was electron microscopic observation. The magnesium prevents the phage from releasing its DNA and from contracting its tail sheath.

The concentrated lysate, 1 to $2 \%$ of the original volume, was incubated for $60 \mathrm{~min}$ with $50 \mu \mathrm{g}$ of deoxyribonuclease per $\mathrm{ml}$ (Worthington Biochemical Corp., Freehold, N.J.). After dialysis versus AAM, $\mathrm{CsCl}$ was added to a density of $1.35 \mathrm{~g} / \mathrm{ml}$. A density gradient was formed by centrifuging for $20 \mathrm{hr}$ at $115,000 \times g$ in a swinging-bucket rotor (Spinco SW39). The phage band and other bands, if present, were collected through a hole in the bottom of the tube. The phage was extensively dialyzed against AAM and kept cold. Phage stocks kept in this manner showed no change in appearance under the electron microscope and no change of transducing activity for 6 weeks or more.

Extraction of DNA from phage. DNA was extracted from PBSH by mild shaking with an equal volume of freshly liquefied phenol in SSC $(0.15 \mathrm{M} \mathrm{NaCl}, 0.015 \mathrm{M}$ sodium citrate) for $30 \mathrm{~min}$. After phase separation by centrifugation, the aqueous phase containing the DNA was dialyzed through three changes of SSC. The ratio of optical densities (OD) at 260 and $280 \mathrm{~nm}$ was always greater than 1.80. Extraction of phenol by shaking with ether was unsuccessful; both sedimentation studies and electron microscopy of phage DNA thus treated showed extensive breakage and degradation. The reasons for this are not apparent.

Heat denaturation of phage DNA in SSC was accomplished by heating the DNA, at a concentration of $15 \mu \mathrm{g} / \mathrm{ml}$, to $100 \mathrm{C}$ in a tightly shut screw-cap tube for $11 \mathrm{~min}$. The sample was then quickly cooled in an ice bath with mild shaking.

Electron microscopy. A three-stage Hitachi HU-11 electron microscope was used at $75 \mathrm{kv}$ at an instrument magnification of 10,000 to 20,000 . Magnification was calibrated by means of a carbon replica grating. Spray mounting of the phage was not possible, since the phage on the grid broke into separate heads and tails and much of the DNA was released from the heads. This inability to spray-mount the phage, since even the gentlest spray method with a modified "respirator" proved too harsh, caused some difficulty in performing electron microscope counts of phage particles. A known concentration of polystyrene latex spheres (Dow) having a diameter of $88 \mathrm{~nm}$ was mixed with a sample of phage in AAM. The mixture was deposited on carbon-evaporated, Formvar-coated Siemens platinum electron microscope grids by the lowered drop method of Pinteric and Taylor (29). Another method used was to spread the mixture on $0.3 \mathrm{~m}$ ammonium acetate (Kleinschmidt method). The spread mixtures were then immediately picked up on similar grids. Grids were shadowed at $20^{\prime}$ with Nichrome or uranium. For observation of phage or lysates, the negative staining method of Horne (18) was used. Potassium phosphotungstate $(1.8 \% ; p \mathrm{H}$ 6.7), was mixed with a drop of the sample and dropdeposited on carbon-backed, Formvar-coated grids. After 1 to $2 \mathrm{~min}$, the drop was slowly sucked off with filter paper. The grids were then immediately observed in the electron microscope.

Electron micrographs of phage DNA were prepared in several ways. Purified phage DNA was mixed with beef cytochrome $c$ in $1 \mathrm{M}$ ammonium acetate to give concentrations of approximately $0.5 \mu \mathrm{g}$ of DNA per $\mathrm{ml}$ and $0.01 \%$ cytochrome $c$. The mixture was spread on $0.1 \mathrm{M}$ ammonium acetate and picked up according to the method of Kleinschmidt (21). Rotary shadowing with uranium was used. Alternatively, DNA was extracted from phage with Freifelder's 
(12) perchlorate technique or with a 10-min treatment with $8 \mathrm{M}$ urea (final concentration, $4 \mathrm{M}$ ) according to the method of Granboulan (14). No DNA denaturation is caused by $4 \mathrm{M}$ urea at room temperature. Instrument magnification for DNA micrographs was $5,000 \times$. The length of the molecules was determined by projection of the electron microscope plates on the wall and by tracing with a map measure (Dietzgen no. 1718).

Velocity sedimentation. Sedimentation coefficients were measured in 12-mm Kel-F cells in a Spinco model E ultracentrifuge with UV optics. DNA concentration was 15 or $18 \mu \mathrm{g} / \mathrm{ml}$ for DNA movingboundary measurements. All such measurements were at 44,770 or $29,500 \mathrm{rev} / \mathrm{min}$. Sedimentation was in SSC unless stated otherwise. Heat-denatured DNA and alkali-denatured DNA were run similarly, at a concentration of $15 \mu \mathrm{g} / \mathrm{ml}$. Sedimentation coefficients were not extrapolated to zero concentration. Both native DNA and denatured phage DNA were also sedimented in a 12-mm Kel-F type II band-forming cell (8) through $\mathrm{CsCl}$ solutions of different density. A 20- to 30- $\mu$ liter amount of purified DNA, with an $O D$ at $260 \mathrm{~nm}$ of 1.3 to 1.5 , was run at $23 \mathrm{C}$ through $\mathrm{CsCl}$ at densities of $1.15,1.25$, and $1.35 \mathrm{~g} / \mathrm{ml}$ in SSC. Speeds used were $29,500,33,450$, and $44,770 \mathrm{rev} / \mathrm{min}$, respectively. Whole-phage PBSH was also sedimented in a type II band-forming piece to determine its sedimentation coefficient. Densities used were 1.15, $1.25,1.30$, and $1.35 \mathrm{~g} / \mathrm{ml}$, and the buffer was AAM. Measurements of this type also yielded the buoyant density of the phage in $\mathrm{CsCl}$, the density at which phage did not sediment or float. All ultracentrifuge absorption photographs were traced on a Joyce Loebl recording densitometer. In the case of band sedimentation, the crest of the density peaks was considered as the point describing the sedimentation velocity. All constants used in the calculation of sedimentation values were taken from Svedberg and Pederson (36).

Density gradient equilibrium ultracentrifugation. The method of Meselson, Stahl, and Vinograd (28) was used to determine the equilibrium distribution of phage DNA in a $\mathrm{CsCl}$ density gradient. An 0.5 - to $2-\mu \mathrm{g}$ amount of DNA was used per run. ${ }^{15} \mathrm{~N}-\mathrm{DNA}$ of $P$. aeruginosa, having a density $1.742 \mathrm{~g} / \mathrm{ml}$ (31), was used as a density marker.

Thermal denaturation of phage DNA. Purified phage DNA in SSC was melted in a Cary model 14 spectrophotometer with an automatic temperature programmer and plotter. The temperature was changed by $1 \mathrm{C}$ increments each $5 \mathrm{~min}$. This allowed the cuvette in which the DNA was being melted to attain temperature equilibrium at each step. DNA was melted up to a temperature $5 \mathrm{C}$ above the temperature at which no increase in OD could be detected and was kept for $10 \mathrm{~min}$ at that temperature. The temperature was then lowered to $20 \mathrm{C}$ below the $\mathrm{T}_{\mathrm{m}}$, and the OD decrease during renaturation was followed. DNA from the host strain was used as control DNA.

Other methods. Sucrose gradient zone centrifugation, in 5 to $20 \%$ sucrose gradients in SSC, was in an SW 39 rotor (Spinco) at $10 \mathrm{C}$ and $37,000 \mathrm{rev} / \mathrm{min}$ for $4.5 \mathrm{hr}$. Fractions were collected from the bottom of the tubes.
Phage DNA was renatured by keeping DNA at $18 \mu \mathrm{g} / \mathrm{ml}$ in SSC in screw-cap tubes at $65 \mathrm{C}$ for $24 \mathrm{hr}$ (26). In some experiments, the renaturation was in a cuvette in a Cary model 14 spectrophotometer.

\section{RESULTS}

Induction. Figure 1 shows the results of MC induction experiments with the four strains described above. Within some $90 \mathrm{~min}$ after resuspension, 168LTT lysed very abruptly, producing phage. Strain CA1 showed slow lysis and produced no phage after MC induction. Strain 168WT produced phage efficiently though part of the culture did not lyse, whereas W23LH showed neither lysis nor detectable phage production.

The results of the induction procedure as described above and shown in Fig. 1 are reproducible. Conditions for obtaining a high phage yield (15) are very limited. Phage production and complete cell lysis took place only when a fast-growing culture was induced in early exexponential phase, up to a cell concentration of approximately $2 \times 10^{7}$ per $\mathrm{ml}$. Slow or no lysis took place when cells were induced later during the exponential phase, and the phage yield was as low as 5 to $10 \%$ of the yield under optimal conditions. In addition, the phage showed extreme density heterogeneity in a $\mathrm{CsCl}$ density gradient, low transducing efficiency, and a low adenine-16 to methionine transduction ratio (15). Increasing the concentration of MC did not improve lysis and phage production under

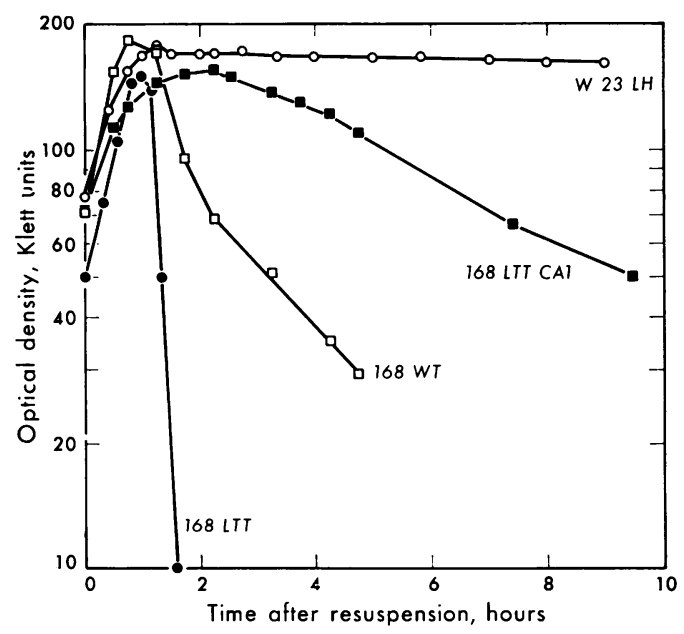

FIG. 1. Growth and lysis of four B. subtilis strains in 0.5 strength Penassay Broth. OD was followed on a Klett colorimeter. Cultures were induced with $4 \mu \mathrm{g}$ of $M C$ per $\mathrm{ml}$ in early exponential phase $\left(1.5 \times 10^{7}\right.$ cells $/ \mathrm{ml}$ ) for $15 \mathrm{~min}$ before resuspension in the same medium without $M C$ 
these conditions, but it arrested cell division and led to eventual cell death and lysis. A small inoculum $(1: 200$ to $1: 500)$ and vigorous aeration were also necessary conditions for an optimal phage yield.

Three other induction methods have been tried: thymineless germination, germination with 5-BUdR, and UV induction. All three methods produced less phage than the MC induction method described. Induction of PBSH with UV irradiation was not limited to a narrow interval during early exponential growth as was required by MC induction. Thymineless germination or 5-BUdR germination produced 5 to $10 \%$ of the phage produced by MC induction. No differences in the appearance of phage PBSH induced by the different methods used were observed in the electron microscope.

Figure 2 shows an electron micrograph of a concentrated crude lysate of induced 168LTT cells. This preparation was kept in $1 \%$ ammonium acetate in the absence of magnesium and therefore most phage tails are contracted. Some phages ( $p)$ and tails $(T)$ appear to be in a state of partial decomposition. The long strands have the appearance and dimensions of bacterial flagella. To examine this, flagella were isolated from the same strain by the method of Abram and Koffler (1). The morphology of these flagella was compared with the long strands in Fig. 2 after negative staining, and we concluded that the latter were indeed flagella. One can observe several flagella which terminate in a "head-like" object $(\mathbf{H H})$. This is typical of the appearance of some flagella in Bacillus strains (2). In the lysate, there are objects $(\mathbf{H})$ attached to the flagella only at points in between the segments of the flagella (see lower left corner in Fig. 2 and Fig. 3A and B). Some of these look like doughnuts and have the dimensions of PBSH heads, although they appear to be empty. Others (Fig. 3A) appear full and have the dimensions of small ribonucleic acid (RNA) phages (6). The resemblance between the flagella and some phage tails is notable (Fig. 3). The segment structure in many parts of the flagella is also present in some of the tails. These tails have not contracted but rather owe their appearance to their partial disintegration. A similar segment structure of flagella at high resolution has been shown by Lowy and Hanson (23). The relationship between the flagella and PBSH phage tails, if any, is under study at our laboratory. In Fig. 3C, some subunits $(\mathrm{S})$ of the tail sheath are lying flat on the grid. One can see that six globular subunits lie peripherally to make the sheath subunit. The globular subunits measure about $5 \mathrm{~nm}$ in diameter. The diameter of the whole unit is about $17 \mathrm{~nm}$. This is equal to the diameter of the extended tail sheath.

Purification. A concentrated crude lysate in AAM was purified in a $\mathrm{CsCl}$ density gradient. Figure 4 shows a photograph of a gradient before fractionation, illuminated with scattered light. Both the phage band and the band containing tails often divided into two parts at close proximity to each other; the lower ones (more dense) consisted of contracted phages or tails, the upper ones contained whole phages or tails. When no $\mathrm{Mg}^{++}$was used, only the contracted bands were present. Figure 5 shows phage PBSH from band no. 1 of Fig. 4 at two magnifications. A uranium-shadowed inset shows the existence of six tail fibers. The phage head is probably an octahedron. Our measurements of the phage dimensions are given in Table 1. These dimensions do not differ significantly from those described by Eiserling for phage $\mathrm{SP} \alpha$. Figure 6 shows the appearance of purified phage tails from band no. 2 in the $\mathrm{CsCl}$ gradient (Fig. 4). The contracted tails show the typical axial striations of contractile tails, whereas in Fig. 3 the cross-striations of the extended tails can be seen. In Fig. 6A, one can also see several tail cores (C). Finally, Fig. 6B shows a phage particle with an empty head from band no. 2 of a $\mathrm{CsCl}$ gradient at high magnification. The tail plate $(\mathbf{P})$ can be seen in this picture.

Purified phage PBSH stock prepared as described above and dialyzed against AAM had a ratio of OD at $260 \mathrm{~nm}$ to $O D$ at $280 \mathrm{~nm}$ of 1.56 to 1.58 . This ratio was quite constant for pure preparations and can be conveniently used as a criterion for purity of the preparation. Since PBSH tail protein has a low tryptophan and tyrosine content (Haas and Yoshikawa, unpublished data), any contaminating protein will drastically lower this ratio. The low tryptophan and tyrosine content of phage tails also explains the relatively high ratio of OD at $260 \mathrm{~nm}$ to $\mathrm{OD}$ at $280 \mathrm{~nm}$, since the tail protein has a low absorption at $280 \mathrm{~nm}$

Electron microscope count of a phage preparation. The first question to be answered is: "How many phage are liberated per cell under optimal induction conditions?" Since phage PBSH did not produce plaques with any bacterial strain thus far tested, an electron microscope count was carried out. Cells $(980 \mathrm{ml})$ were induced at early exponential phase in low-phosphate Penassay broth at a concentration of $1.5 \times 10^{7}$ cells/ $\mathrm{ml}$. Phage was purified and counted under the electron microscope while mixed $1: 1: 8$ with $0.1 \%$ bovine serum albumin and $880-\mathrm{nm}$ polystyrene latex particles. An exact cell count was done immediately before the addition of $4 \mu \mathrm{g}$ 


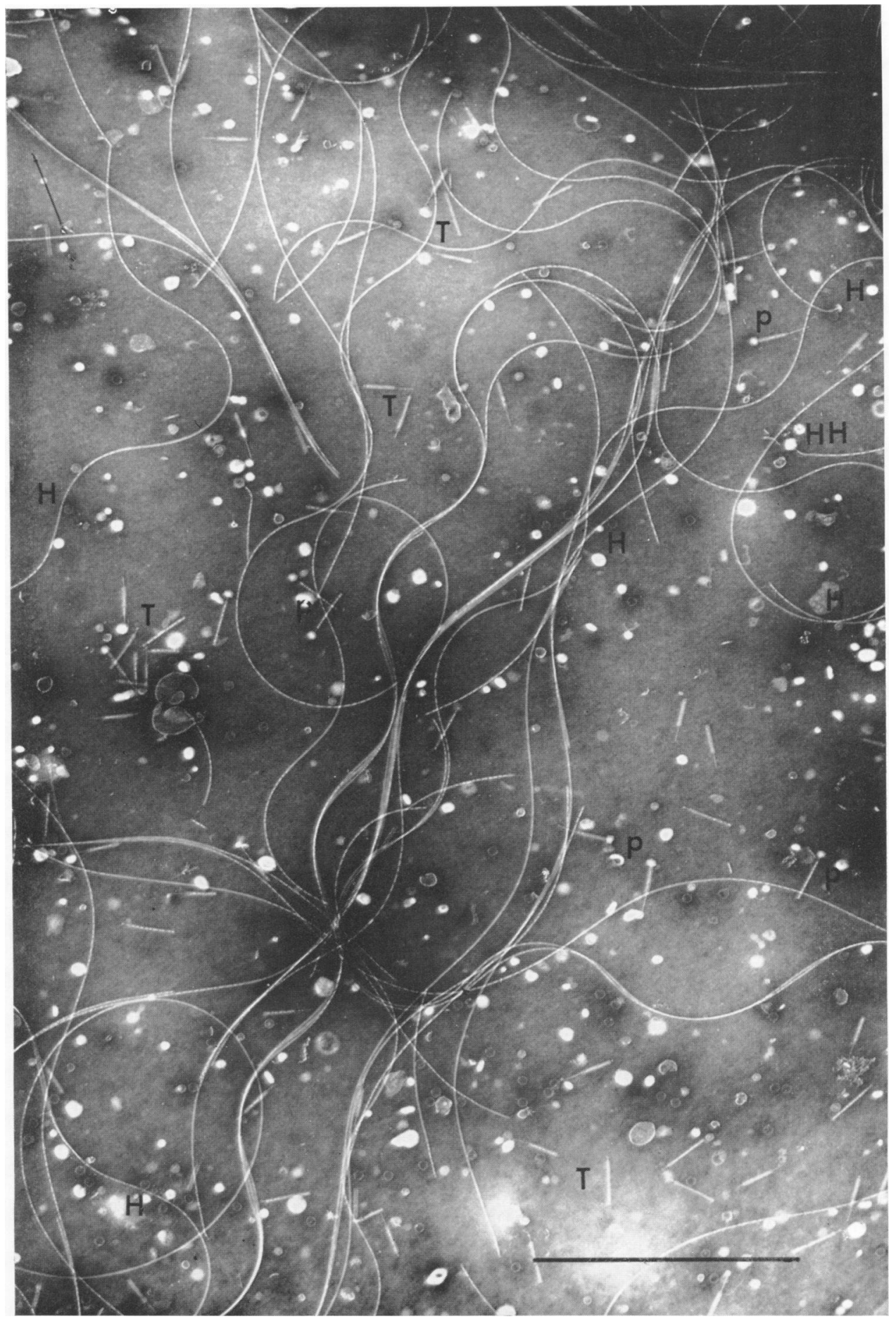

Fig. 2. Crude concentrated lysate of strain 168LTT induced with MC in Penassay Broth. Resuspended in $1 \%$ ammonium acetate without magnesium. Scale, $1 \mu \mathrm{m}$. 


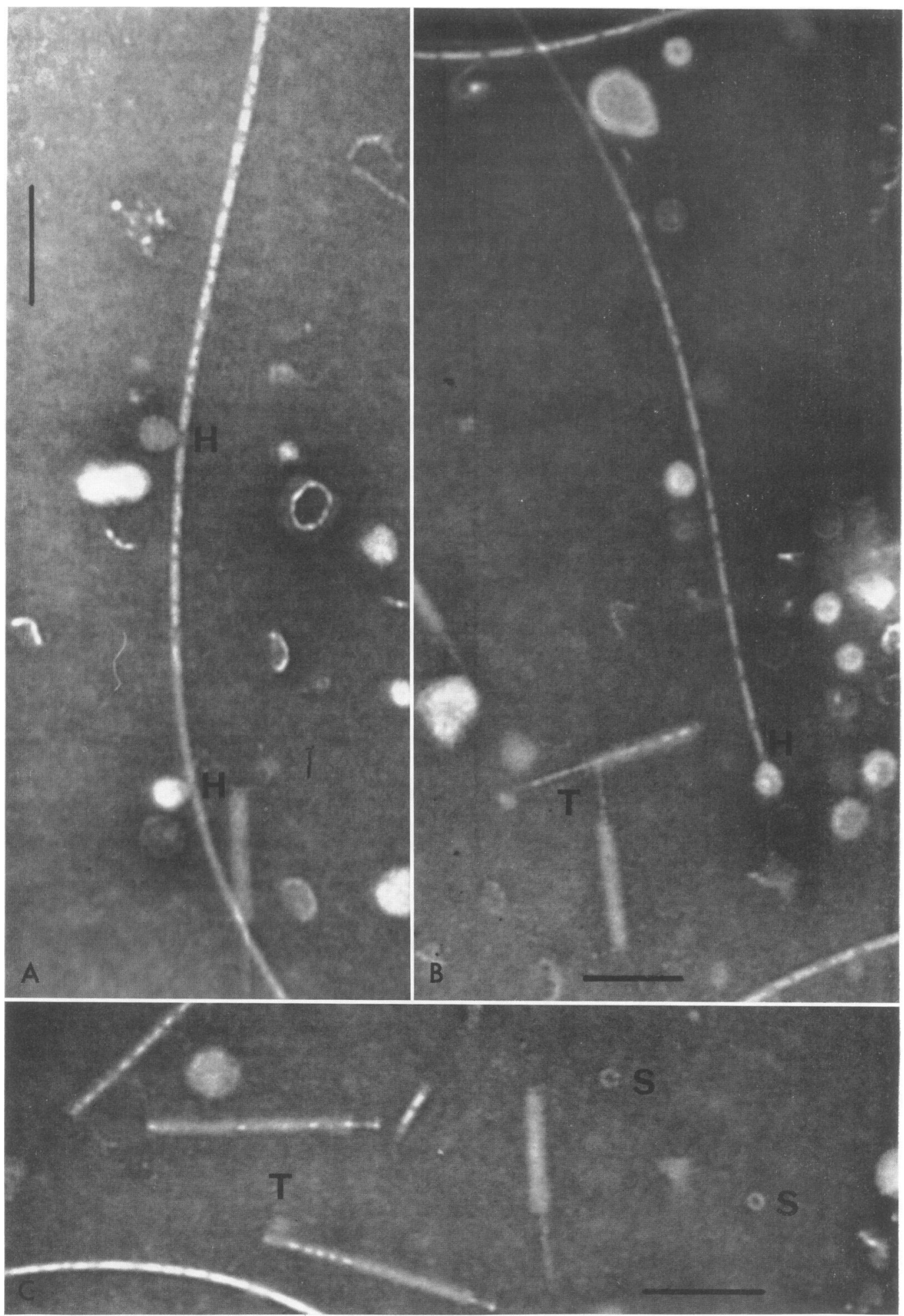

FIG. 3. Crude concentrated lysate of strain 168LTT induced with MC in Penassay Broth. Resuspended in 1\% ammonium acetate. No magnesium. Scales, $100 \mathrm{~nm}$. 


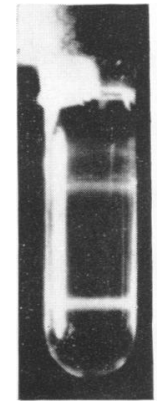

$$
\begin{aligned}
& \text { BAND APPEARANCE UNDER DENSITY } \\
& \text { NO. ELECTRON MICROSCOPE (g/cc) } \\
& \text { Top Flagella } \\
& 3 \text { Amorphous material } \\
& 2 \div \text { Tails and empty heads } \\
& \text { - Contracted tails } \\
& 1 \text { Whole phage } \\
& \text { hage with } \\
& \text { contracted tail sheaths }
\end{aligned}
$$

Fig. 4. Purification of PBSH in a CsCl density gradient. A 200-ml crude lysate was concentrated as described in Materials and Methods. The resulting pellets were mixed with $\mathrm{CsCl}$ in AAM to give $\rho=1.30$ $\mathrm{g} / \mathrm{ml}$ and centrifuged in a swinging-bucket rotor as described.

of MC per ml. It was assumed that MC stops cell division abruptly (30). This assumption is probably valid, since exposure of strain 168LTT to MC caused the appearance of filaments within a few minutes. After lysis, the lysate was processed with extreme care to lose as little phage as possible. The following results were obtained: $1.47 \times 10^{10}$ cells in $980 \mathrm{ml}$ were induced; total phage count, 1,136; total PSL count, 770; total phage yield, $1.58 \times 10^{12}$ in $1.35 \mathrm{ml}$ of $O D$ at $260=$ $1.87 ; 107$ phage were liberated per cell. From this experiment, we also obtained a calibration value for the concentration of PBSH in an AAM stock solution: a stock of $O D$ at $260 \mathrm{~nm}=1.0$ contains $6.25 \times 10^{11} \mathrm{phage} / \mathrm{ml}$. The stock has a ratio of $\mathrm{OD}$ at $260 \mathrm{~nm} / \mathrm{OD}$ at $280 \mathrm{~nm}=1.57$.

The phage count given above was determined from an induction experiment not quite at optimal conditions. Later experiments showed that under optimal conditions as many as 400 phage are commonly liberated from each cell. We performed no count of free tails produced after induction, but from OD values of the total tail band (band no. 2 in Fig. 4) we estimated that about equal numbers of free tails and whole phage were found in a typical lysate.

Physical properties of phage PBSH. The density of phage PBSH and the density of its tails in $\mathrm{CsCl}$ were determined from the positions of the respective bands in a fractionated $\mathrm{CsCl}$ density gradient. The density of the phage was also determined by means of band sedimentation through $\mathrm{CsCl}$ solutions of various densities. PBSH whole phage with extended tail sheaths had a density of $1.375 \mathrm{~g} / \mathrm{ml}$; tails with extended sheaths showed a density of 1.295 . Taking the density of PBSH DNA as 1.705 (see Table 2), the weight per cent DNA content of the phage is $16.5 \%$.
The volume of a phage particle, calculated from the electron microscopic measurements listed in Table 1 , is $81 \times 10^{-18} \mathrm{~cm}^{3}$. With a density of 1.375 , this gives a particle weight of $67.5 \times 10^{6}$ daltons. At $16.5 \%$ DNA content, we expect a DNA complement of $11.1 \times 10^{6}$ daltons. PBSH particle weight was also determined by means of band sedimentation. Figure 7 shows a plot of the sedimentation values. Extrapolation to unit density gives a sedimentation constant of $S=248$. This plot also confirmed the values obtained in density measurements for the whole phage.

To calculate the particle weight from the sedimentation data, the translational frictional coefficient of the phage was calculated according to the formula of Bloomfield, van Holde, and Dalton (4).

The translational frictional coefficient for phage PBSH was calculated with a computing program based on a program kindly supplied by V. Bloomfield. At an angle of $135^{\circ}$ between the phage tail and six tail fibers, the resulting calculated frictional coefficient is $46.4 \mathrm{~nm}$. With a partial specific volume of 0.738 and using constants given by Svedberg and Pederson (36), a value of $54 \times 10^{6}$ daltons was found for the molecular weight of phage PBSH. This value is low, as compared to the value of $67.5 \times$ $10^{6}$ daltons obtained above.

Physical properties of PBSH DNA. DNA was isolated from pure PBSH stock as described above. Boundary velocity sedimentation in SSC was performed on native DNA and on heatdenatured DNA. Experiments were done by conventional filling of the centrifuge cells with a needle and by filling the cells from the window end. These double runs were performed for native and for heat-denatured phage DNA. No difference in sedimentation coefficients could be detected for the two filling methods, indicating that no breakage of the DNA strands took place (9). Band sedimentation was done through SSC-buffered $\mathrm{CsCl}$ solutions or through alkali$\mathrm{CsCl}$ solutions $(0.2 \mathrm{~N} \mathrm{NaOH})$. Figure 8 shows the results obtained by the band sedimentation experiments. The results for all four kinds of experiments are summarized in Table 2. The sedimentation coefficients were converted to molecular weights by use of the formulas of Eigner and Doty (10).

PBSH DNA sediments with sharp boundaries both in native and denatured states in the movingboundary experiments, indicating molecular weight homogeneity and the absence of singlechain breaks (13). In the band sedimentation experiments, no evidence for any fast-moving or slow-moving DNA was obtained. It was 

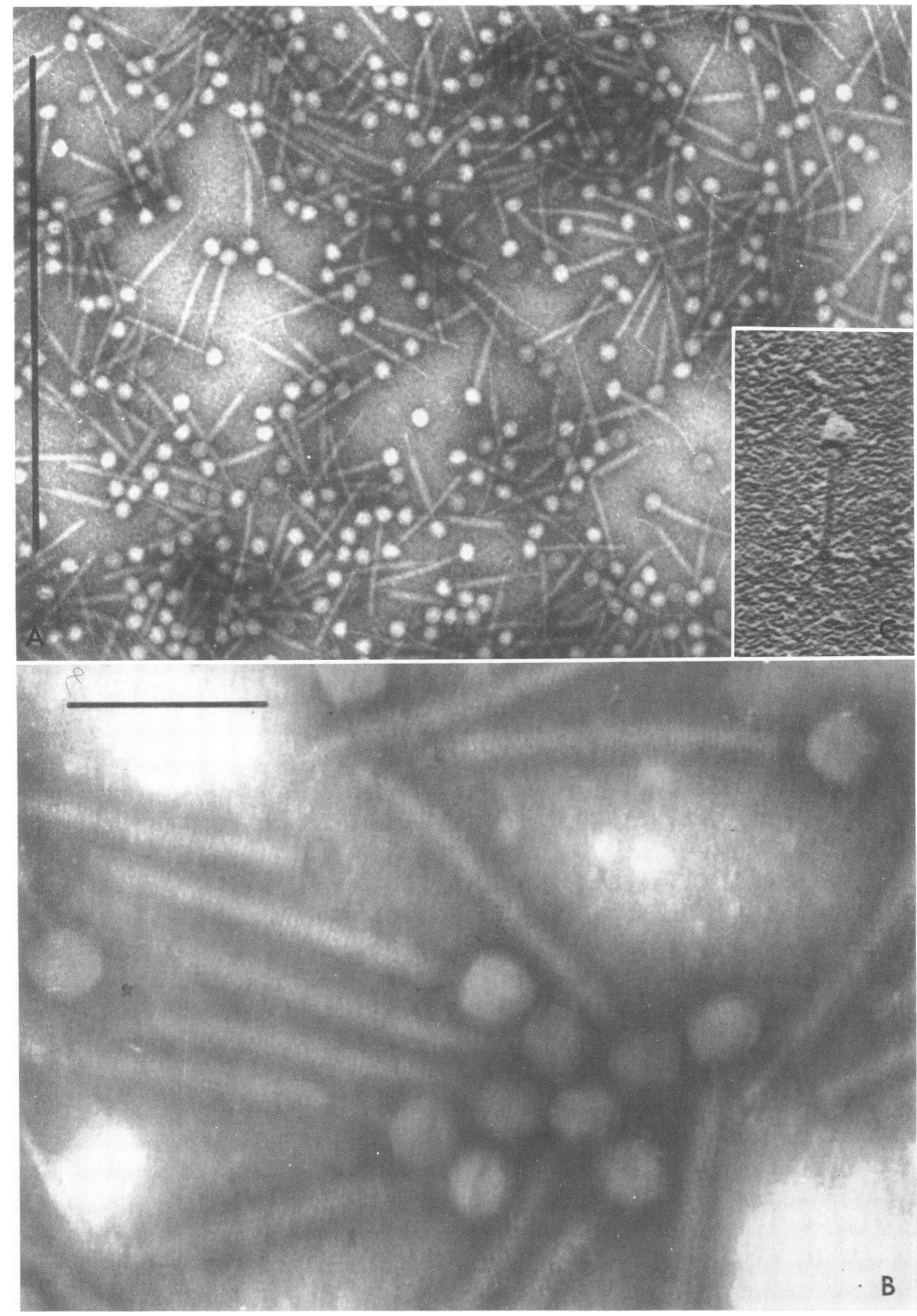

FIG. 5. Purified phage PBSH. Band no. 1 in Fig. 4 was dialyzed versus AAM and negatively stained for electron microscopy. Scales: $A, 1 \mu \mathrm{m} ; \mathrm{B}, 100 \mathrm{~nm} ; \mathrm{C}, \times 170,000$. 
assumed, therefore, that very few or no circular DNA molecules were present in our phage DNA preparations. The absence of circular PBSH molecules has also been verified by electron

TABLE 1. Dimensions of PBSH

\begin{tabular}{|c|c|}
\hline Determination & Size \\
\hline & $n m$ \\
\hline Head (diameter)... & 41 \\
\hline Tail ............. & $17 \times 200$ \\
\hline Sheath contracted... & $20 \times 120$ \\
\hline Tail fibers $\ldots \ldots \ldots \ldots \ldots \ldots$ & $3 \times 70$ \\
\hline Tail core $\ldots \ldots \ldots \ldots \ldots$ & $7 \times 200$ \\
\hline
\end{tabular}

microscopy (see below). Not one circular DNA filament could be detected in more than 2,000 separate molecules examined.

The formula converting the sedimentation coefficient for single-stranded DNA in SSC to molecular weight, $S_{\mathrm{o}}=0.022 \mathrm{M}_{\mathrm{w}}{ }^{0.48}(10)$, is not suitable for converting the extrapolated sedimentation data from band sedimentation (Fig. 8B) in high salt. Extrapolation to a density of 1.0 does not eliminate the effect of high ionic strength on the sample, which causes an increase in its sedimentation coefficient. Taking this into account, the calculated molecular weights for single-stranded DNA from both
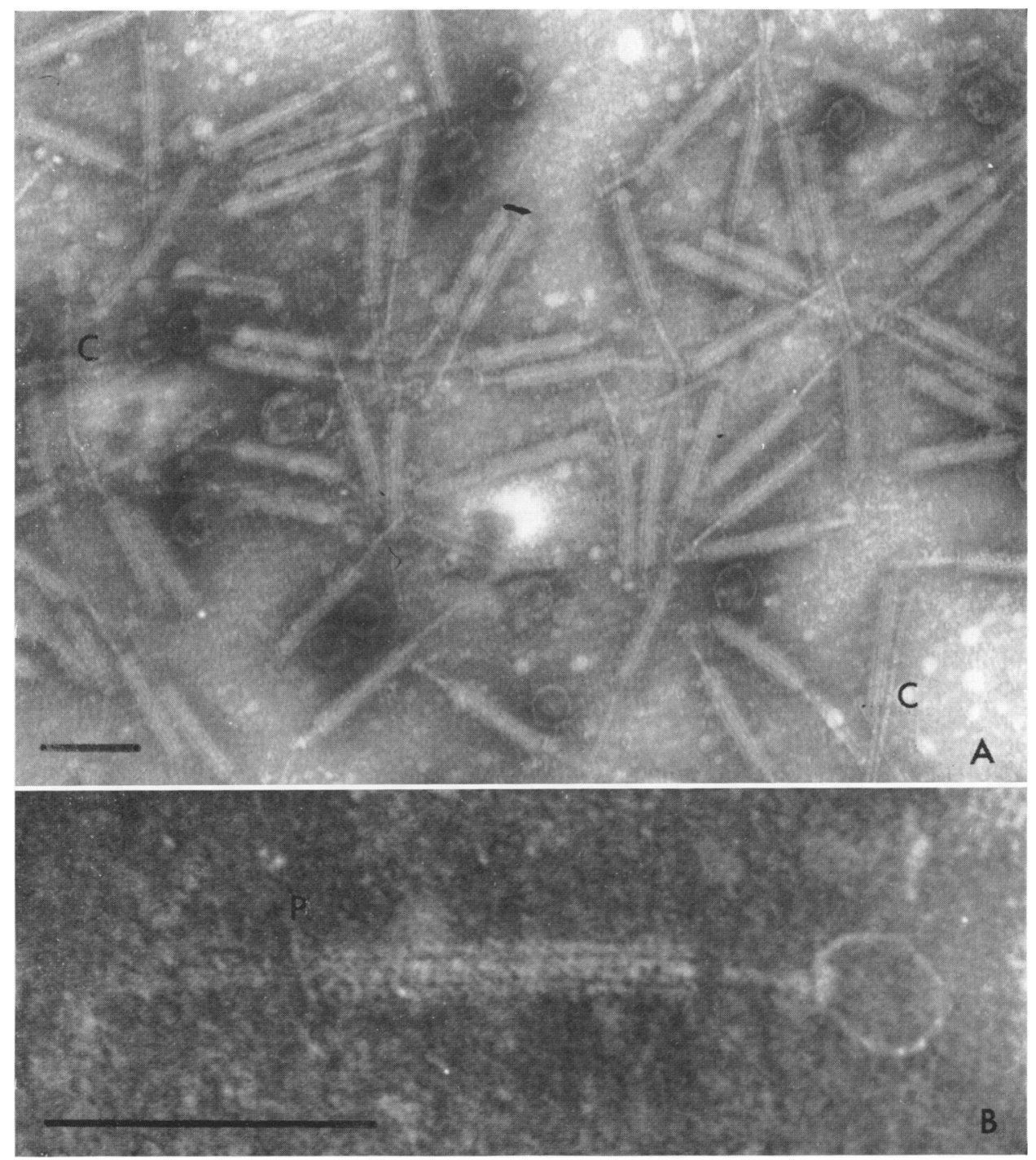

Fig. 6. Phage tails in $1 \%$ ammonium acetate. Band no. 2 of Fig. 4. Both tails and tails connected to empty heads can be found in the tail band. In B, the neck connecting the empty head to the tail core as well as the tail plate can be seen. Scales, $100 \mathrm{~nm}$. 
sedimentation experiments and contour measurements are in good agreement (Table 2).

The calculated molecular weight for native double-stranded PBSH DNA was significantly larger than the molecular weights obtained from contour length measurements and from singlestrand sedimentation results. Sedimentation coefficients obtained for different batches of DNA and measured by boundary and band sedimentation were substantially constant. To determine one possible reason for the discrepancy in molecular weight, the sedimentation behavior of PBSH DNA was measured in various ionic strength buffers. If regions of the double-stranded molecules are not equally rigid, the hydrodynamic behavior of these molecules should be intermediate between that of completely doublestranded and that of single-stranded DNA. Any effect causing increased flexibility of the double-stranded DNA molecule will prevent the

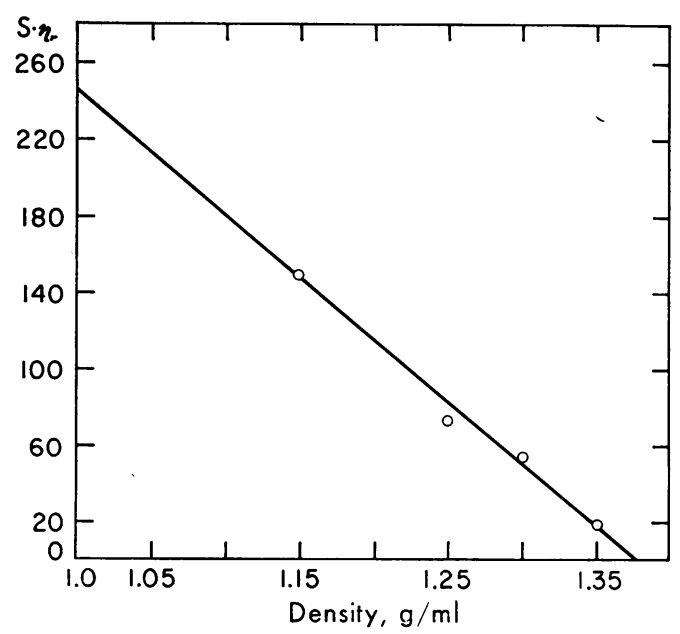

FIG. 7. Band sedimentation of whole-phage PBSH through $\mathrm{CsCl}$ solutions of different density (8). Runs were made in a 12-mm Kel-F type II band-forming cell. Density of the CsCl solutions in AAM was determined by measuring their refractive index. use of the Eigner-Doty equation for doublestranded DNA. One reason for increased flexibility may be the existence of a region of high adenine plus thymine (AT) content. One expects DNA of high AT content to be more flexible than double-stranded DNA of lower AT content (41). In such cases, the equation of Eigner and Doty for double-stranded DNA will give too high molecular weights. The hydrodynamic properties of single-stranded DNA are strongly dependent on ionic strength as a result of changes in conformation. Studier reported the sedimenta-

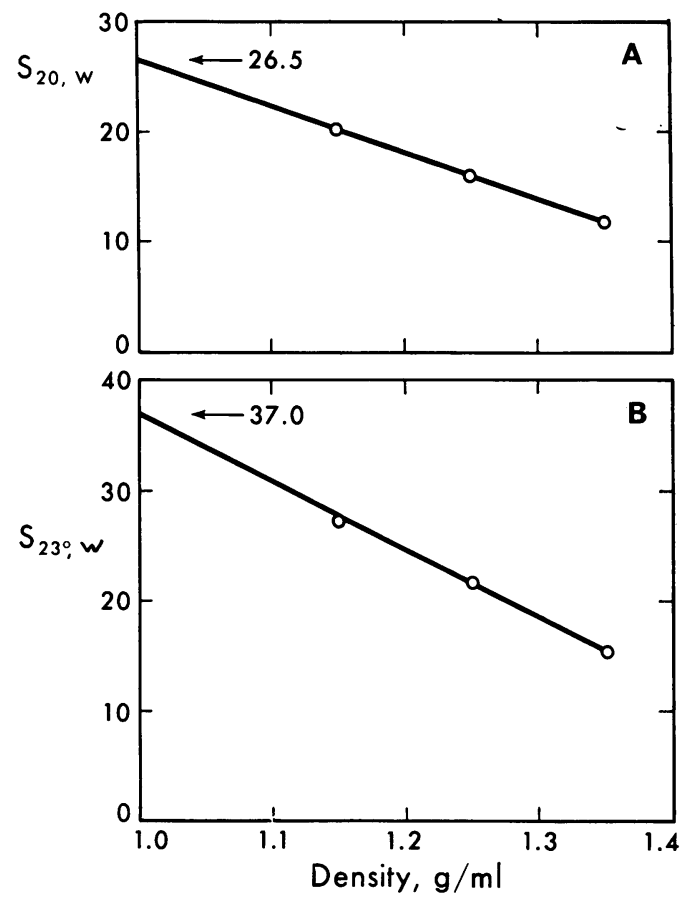

FIG. 8. Band sedimentation of phenol-extracted PBSH DNA. (A) Native DNA was sedimented through solutions of $\mathrm{CsCl}$ in SSC of different densities (8). (B) Alkali-denatured $(0.2 \times \mathrm{NaOH}) \mathrm{PBSH} D N A$ in alkali-CsCl solutions ( $p H$ 12.5). Densities were determined as in Fig. 7.

TABLE 2. Sedimentation constants, contour length, and corresponding calculated molecular weight values of purified PBSH DNA and denatured PBSH DNA

\begin{tabular}{l|l|l|l}
\hline \multicolumn{1}{c|}{ Type of DNA } & \multicolumn{1}{|c}{ Band sedimentation } & \multicolumn{1}{|c}{ Boundary sedimentation } & \multicolumn{1}{c}{ Electron microscopy } \\
\cline { 2 - 3 } Native & $\begin{array}{l}S_{20, \mathrm{w}}=26.5 \\
\mathrm{MW}^{b}=13.8 \times 10^{6} \text { daltons }\end{array}$ & $\begin{array}{l}S_{20, \mathrm{w}}=25.2 \\
\mathrm{MW}=12.2 \times 10^{6} \text { daltons }\end{array}$ & $\begin{array}{l}\text { Length }=4.74 \\
\mathrm{MW}=9.3 \times 10^{6} \text { daltons }\end{array}$ \\
Denatured & $\begin{array}{l}S_{23^{\circ}}=37.0 \text { (alkali) } \\
\mathrm{MW}=5.6 \times 10^{6} \text { daltons }\end{array}$ & $\begin{array}{l}S_{20, \mathrm{w}}=34.8 \text { (heat) } \\
\mathrm{MW}=4.68 \times 10^{6} \text { daltons }\end{array}$ & \\
\hline
\end{tabular}

${ }^{a}$ All boundary sedimentations were done in SSC. Band sedimentations were performed in $\mathrm{CsCl}$ solutions with SSC or in $\mathrm{CsCl}$ solutions in the presence of $0.2 \mathrm{~N} \mathrm{NaOH}$.

${ }^{b}$ Molecular weight. 
tion coefficient of native double-stranded DNA to be independent of ionic strength (34). Unlike Studier's results, Hearst (private communication) found the sedimentation coefficient of doublestranded DNA to be dependent on ionic strength as will also be shown below.

A batch of purified PBSH DNA was divided into three parts and extensively dialyzed against $0.1 \times \mathrm{SSC}, \mathrm{SSC}$, and $10 \times \mathrm{SSC}$, respectively $\left(0.0195,0.195\right.$, and $1.95 \mathrm{M} \mathrm{Na} \mathrm{Na}^{+}$. Boundary sedimentation experiments were performed as described above. The sedimentation coefficient of PBSH DNA varied from 22.2 to 29.7 with a 100 fold ionic strength increase (Table 3 , column 2).

As a control experiment, calf thymus DNA (CT DNA; Worthington Biochemical Corp., high molecular weight) in SSC was repurified by two alcohol precipitations and was fractionated simultaneously with PBSH DNA in a 5 to $20 \%$ sucrose gradient. The CT DNA fraction which sedimented about the same distance as $\mathrm{PBSH}$

TABLE 3. Effect of salt concentration on sedimentation coefficient of PBSH DNA

\begin{tabular}{|c|c|c|c|}
\hline \multirow{2}{*}{ Determination } & \multicolumn{2}{|c|}{$\begin{array}{l}\text { PBSH DNA (43\% } \\
\text { guanine plus cytosine) }\end{array}$} & \multirow{2}{*}{$\begin{array}{l}\text { Calf thymus } \\
\text { DNA (42\% } \\
\text { guanine plus } \\
\text { cytosine) } \\
S_{20, w}\end{array}$} \\
\hline & $S_{20, \mathrm{w}}$ & $\underset{(\text { corrected) }}{S_{20, \mathrm{w}}}$ & \\
\hline $\begin{array}{l}0.1 \times \mathrm{SSC} \\
\text { SSC } \\
10 \times \mathrm{SSC}\end{array}$ & $\begin{array}{l}22.2 \\
25.2 \\
29.7\end{array}$ & $\begin{array}{l}24.5 \\
25.2 \\
27.1\end{array}$ & $\begin{array}{l}19.0 \\
21.0 \\
23.0\end{array}$ \\
\hline
\end{tabular}

a The sedimentation coefficients of PBSH DNA in $0.1 \times$ SSC and in $10 \times$ SSC were multiplied by the ratio of CT DNA sedimentation constants, $S_{20, \mathrm{w}}(\mathrm{SSC}) / S_{20, \mathrm{w}}(0.1 \times \mathrm{SSC})$ and $S_{20, \mathrm{w}}(\mathrm{SSC}) /$ $S_{20, w}(10 \times \mathrm{SSC})$, respectively. This "standardizes" the salt-dependent sedimentation coefficients of PBSH DNA relative to the salt dependence of the CT DNA sedimentation coefficient. These corrected values, given in column 3 , show the salt-dependent variation of the PBSH DNA sedimentation coefficients over and above that expected for the "standard" used.
DNA was considered to have a molecular weight about equal to that of the latter and was used for the control experiment. This CT DNA sample was divided into three parts, extensively dialyzed against $0.1 \times$ SSC, SSC, and $10 \times \mathrm{SSC}$, and sedimented in boundary sedimentation at $18 \mu \mathrm{g} / \mathrm{ml}$ and $44,770 \mathrm{rev} / \mathrm{min}$ (column 4 of Table 3 ). The sedimentation coefficients varied from 19.0 to 23.0 for a 100 -fold ionic strength increase.

The sedimentation data for CT DNA were used to correct the data for PBSH DNA so as to exclude the "normal" ionic strength dependence of native double-stranded DNA. The normalized values are given in column 3 of Table 3 . These corrected sedimentation coefficients of PBSH DNA still show a salt dependence. Therefore, the possibility exists that PBSH DNA has one or more areas which are not completely hydrogen-bonded or else regions which convey to the molecule more flexibility than that of native CT DNA.

The melting temperature $\left(T_{m}\right)$ of PBSH DNA was determined as described above. DNA extracted from strain 168LTT by the method of Marmur (26) was melted as a control. The reproducibility of the system used was estimated at $0.5 \mathrm{C}$, the absolute temperature adjustment at approximately $1.0 \mathrm{C}$. Under these conditions, no difference could be detected between the $T_{m}$ of PBSH DNA and the $T_{m}$ of control DNA. The width of the melting region was virtually equal for the two DNA samples, indicating similar average base compositions. The increase in OD at $260 \mathrm{~nm}$ for the two DNA samples was $35 \%$ each. The 168LTT DNA renatured a total of $45 \%$ of the increase in OD at $260 \mathrm{~nm}$, whereas PBSH DNA renatured only $35 \%$ of the OD increase after heating. This probably reflects differences in molecular weight (27).

The density of PBSH DNA in $\mathrm{CsCl}$ and in $\mathrm{Cs}_{2} \mathrm{SO}_{4}$ was determined in the analytical ultracentrifuge with ${ }^{15} \mathrm{~N}$-DNA of $P$. aeruginosa as marker and separately with 168LTT DNA as control. No difference in density between PBSH DNA and 168LTT DNA could be detected. The

TABLE 4. Physical properties of PBSH and PBSH DNA

\begin{tabular}{l|c|c|c|c}
\hline \multicolumn{1}{c|}{ Determination } & PBSH & PBSH DNA & Denatured DNA & Renatured DNA \\
\cline { 2 - 3 }$S_{20, w}$ & 248 & $25.35 \pm 0.15$ & $35.9 \pm 1.1$ & Heterogeneous \\
Molecular weight & $68 \times 10^{6}$ & $12.35 \pm 0.45$ & $4.97 \pm 0.29$ & Heterogeneous \\
$\rho(\mathrm{CsCl})$ & 1.375 & 1.705 & 1.720 & 1.709 \\
$\rho\left(\mathrm{Cs}_{2} \mathrm{SO}_{4}\right)$ & & 1.424 & \\
$\mathrm{~T}_{\mathrm{m}}$ & $43^{b}$ & 46.0 & $43^{b}$ & \\
$\mathrm{GC} \% c^{a}$ & & $43^{b}$ & & \\
\hline
\end{tabular}

a Guanine plus cytosine.

${ }^{3}$ From density measurement (30). 


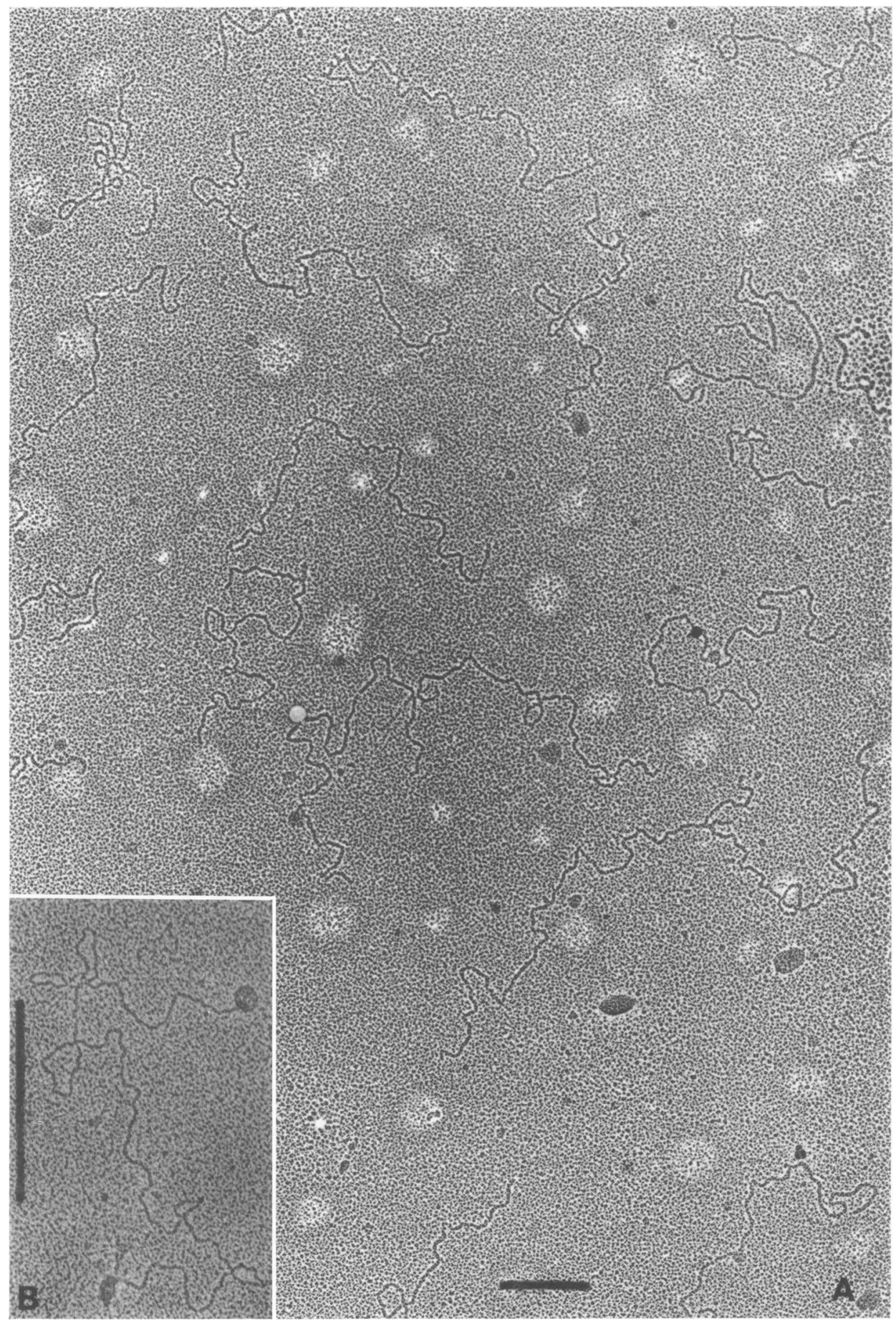

Fig. 9. PBSH DNA. (A) DNA extracted from purified phage PBSH by gentle phenol shaking was prepared on grids by spreading on 0.1 y ammonium acetate and shadowing with uranium at $7^{\circ}(21)$. (B) DNA shocked. Obtained from phage PBSH by $4 \mathrm{x}$ urea treatment and spread as in $(A)$. Scales, $1 \mu \mathrm{m}$. 
physical properties of phage PBSH and of PBSH DNA are summarized in Table 4.

Contour length measurement of PBSH DNA. A field of PBSH DNA filaments spread by the Kleinschmidt technique is depicted in Fig. 9A. In Fig. 9B, one DNA filament prepared by the urea method of Granboulan (14) is shown. Using the urea extraction method, about one-half of the DNA filaments are seen to emerge from ruptured heads, and the other half through the tail end. In Fig. 9B, the filament is seen coming out of a head with a piece of broken tail connected to the other end. Figure 10 shows a histogram of contour lengths of 103 randomly chosen filaments. This mean length is $4.74 \pm 0.16 \mu \mathrm{m}$. The molecular weight of the DNA was calculated from this to be $(9.3 \pm 0.31) \times 10^{6}$ daltons, using the value of 196 daltons per $0.1 \mathrm{~nm}$ of DNA in the B configuration (38).

\section{DISCUSSION}

Given suitable conditions, induction of strain 168LTT with MC caused the release of a large number of phage. Under other conditions, a small number of phage were produced, and occasionally no phage at all could be detected in a lysate. This may be a reason that, despite the large amount of reported work on various strains of $B$. subtilis, these prophages have remained undetected for many years. The optimal conditions for induction and production of a high phage yield were similar to the conditions necessary for induction and subsequent vegetative replication of other phages $(24,25)$. One exception is the stringent need for induction during early exponential phase. This indicates that the development of PBSH after prophage induction is dependent on the host-cell metabolism much more than induction and development of other prophages. It is suggested that induction with MC is similar to induction by UV irradiation, namely, that an immunity-destroying substance is synthesized after MC treatment (40). Then induction and subsequent vegetative phage growth may be dependent on the outcome of two competing reactions: the synthesis of an immunity derepressor and degradation of much of the cellular synthetic apparatus caused by the action of MC (37). If MC induction takes place during early exponential growth, enough immunity derepressor is produced to cause prophage induction, after which the cellular synthetic apparatus is used in phage production. If cellular disintegration takes place before the immunity derepressor has attained the necessary level in the cells, little phage is produced but delayed cell lysis still occurs.

Cell lysis of some bacterial species after MC

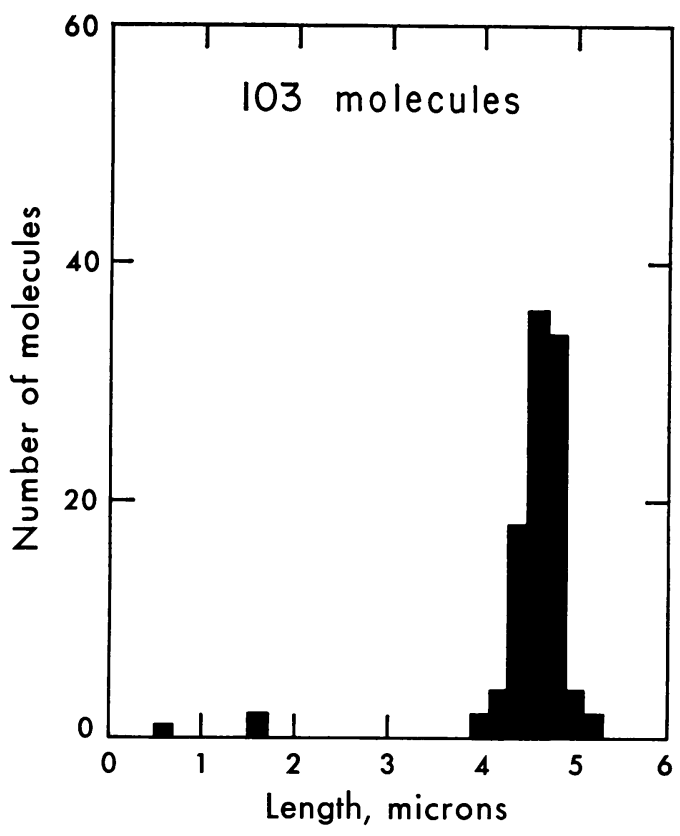

FIG. 10. Length distribution of PBSH DNA. Length interval, $0.2 \mu \mathrm{m}$.

treatment is arrested by the addition of chloramphenicol (CM) during the first 20 min after MC addition; however, when $\mathrm{CM}$ is added at $40 \mathrm{~min}$ or later, cell lysis still occurs, though the time required to yield a detectable degree of lysis is considerably extended (3). Though no evidence of phage production was given by these authors, these results are consistent with the premise that production of a protein shortly after induction is eventually responsible for cell lysis. One of the early proteins may be the immunity derepressor.

With a contour length of $4.74 \mu \mathrm{m}$ and a molecular weight of $(12.35 \pm 0.45) \times 10^{6}$ daltons, PBSH DNA fills the vacancy in the table of available phage DNA molecules as reported by Thomas (38). The discrepancy found for the molecular weight of double-stranded PBSH DNA may be the result of two different effects. First, the contour length measurement results may be too low, since DNA was spread on $0.1 \mathrm{M}$ ammonium acetate. According to Lang et al. (22) this may give values too small by $5 \%$. Inman (19) reported that this discrepancy is as much as $30 \%$ for salts other than ammonium acetate. We assume, therefore, that our measurements gave a value which is too low. If we accept Inman's values, a molecular weight of $12.1 \times 10^{6}$ results, in agreement with $(12.35 \pm 0.45) \times 10^{6}$ daltons obtained. In that case, the values for denatured DNA are too small. 
Second, the excessive salt dependence of the native PBSH DNA (Table 3) suggests that part of the discrepancy in the results for the molecular weight of PBSH DNA lies in an increased flexibility of native PBSH DNA. We have no evidence for the existence of single-strand interruptions, unless these occur close to the ends of the molecules. We are suggesting, therefore, that PBSH DNA has small regions of incomplete hydrogen bonding or possibly a region or regions of high AT content along the molecule, which cause formation of "flexible joints." Lowered stability of high AT-containing regions has also been suggested by the experiments of Wingert and von Hippel (41). The change in the DNA hydrodynamic properties then rules out use of the Eigner and Doty (10) relation converting sedimentation coefficients to molecular weight for double-stranded DNA.

Bloomfield et al. (4) showed that calculations based on their formula give low molecular weights, as compared to molecular weights obtained from viscosity and light scattering data. One explanation advanced was that the discrepancy is due to differences between the structures observed in electron micrographs and those in solution. This explanation is not valid in the present case, since both values obtained were based on electron microscope data. As the value for phage density is more reliable than the other experimental data, one is led to regard the value of $68 \times 10^{6}$ daltons as the better value of PBSH molecular weight. This leads to the conclusion that calculation of the translational frictional coefficient (4) underestimates the molecular weight due to hydrodynamic interactions which are not considered in the procedure, since the "shell model" disregards such interactions.

\section{ACKNOWLEDGMENTS}

We thank Estelle Cook, Joyce Cerwin, and Barbara Jansen for their technical assistance and Thomas $\mathbf{H}$. Jukes for his interest and support of this investigation. We also thank R. Glaeser, Donner Laboratory, for advice and for electron microscope facilities.

This investigation was supported by grant NsG 479 from the National Aeronautics and Space Administration to the University of California, Berkeley.

\section{LITERATURE CITED}

1. Abram, D., and H. Koffler. 1964. In vitro formation of flagella-like filaments and other structures of flagellin. J. Mol. Biol. 9:168-185.

2. Abram, D., A. E. Vatter, and H. Koffler. 1966. Attachment and structural features of flagella of certain bacilli. J. Bacteriol. 91:2045-2068.

3. Altenbern, R. A., and H. B. Stull. 1965. Inducible lytic systems in the genus Bacillus. J. Gen. Microbiol. 39:53-62.

4. Bloomfield, V., K. E. van Holde, and W. O. Dalton. 1967. Frictional coefficient of multisubunit structures. II. Application to proteins and viruses. Biopolymers 5:149-159.

5. Bradley, D. E. 1965 . The isolation and morphology of some new bacteriophages specific for Bacillus and Acetobacter species. J. Gen. Microbiol. 41:233-241.

6. Bradley, D. E. 1967. Ultrastructure of bacteriophages and bacteriocins. Bacteriol. Rev. 31 :230-314.

7. Bradley, D. E., and C. A. Dewar. 1966. The structure of phage-like objects associated with non-induced bacteriocinogenic bacteria. J. Gen. Microbiol. 45:399-408.

8. Bruner, R., and J. Vinograd. 1963. The evaluation of standard sedimentation coefficients of sodium RNA and sodium DNA from sedimentation velocity data in concentrated $\mathrm{NaCl}$ and $\mathrm{CsCl}$ solution. Biochim. Biophys. Acta 108: 18-29.

9. Davison, P. F., and D. Friefelder. 1966. Lability of singlestranded DNA to hydrodynamic shear. J. Mol. Biol. 16: 490-502.

10. Eigner, J., and P. Doty. 1965. The native, denatured and renatured states of deoxyribonucleic acid. J. Mol. Biol. 12: 549-580.

11. Frampton, E. W., and B. R. Brinkley. 1965. Evidence of lysogeny in derivatives of Escherichia coli. J. Bacteriol. 90: 446-452.

12. Freifelder, D. 1965. A novel method for the release of bacteriophage DNA. Biochem. Biophys. Res. Commun. 18:141-144.

13. Freifelder, D., and P. F. Davidson. 1963. Physiochemical studies on the reaction between formaldehyde and DNA. Biophys. J. 3:49-63.

14. Granboulan, N., and A. Niveleau. 1967. Étude au microscope électronique du RNA du reovirus. J. Microscopie 6:23-30.

15. Haas, M., and H. Yoshikawa. 1968. Defective bacteriophage PBSH in Bacillus subtilis. II. Intracellular development of the induced prophage J. Virol. 3:248-260.

16. Haas, M., and H. Yoshikawa. 1968. Replication of a defective prophage of $B$. subtilis and its location on the chromosome. Biophys. J. 8A :-63.

17. Hideya, E., K. Ayabe, K. Amako, and K. Takeya. 1964. Inducible phage of Escherichia coli 15. Virology 25:469-471.

18. Horne, R. W. 1966. Negative staining, p. 328-335. In D. Kay (ed.). Techniques in electron microscopy, 2 nd ed.

19. Inman, R. B. 1967. Some factors affecting electron microscopic length of deoxyribonucleic acid. J. Mol. Biol. 25:209216.

20. Ionesco, H., A. Ryter, and P. Schaeffer. 1964. Sur un bactériophage hébergé par la souche Marburg de Bacillus subtilis. Ann. Inst. Pasteur 107:764-776.

21. Kleinschmidt, A. K., D. Lang, D. Jacherts, and R. K. Zahn. 1962. Darstellung and langenmessungen des gesamten desoxyribonucleinsaure inhaltes von T2-bacteriophagen. Biochim. Biophys. Acta 61:857-864.

22. Lang, D., H. Bujard, B. Wolff, and D. Russell. 1967. Electron microscopy of size and shape of viral DNA in solutions of different ionic strengths. J. Mol. Biol. 23:163-181.

23. Lowy, J., and J. Hanson. 1965. Electron microscope studies of bacterial flagella. J. Mol. Biol. 11:293-313.

24. Lwoff, A., and A. Gutmann. 1950. Recherches sur un Bacillus megathérium lysogène. Ann. Inst. Pasteur. 78:711-739.

25. Lwoff, A., L. Siminovitch, and N. Kjelgaard. 1950. Induction de la production de bactériophages chez une bactérie lysogène. Ann. Inst. Pasteur. 79:815-859.

26. Marmur, J. 1961. A procedure for the isolation of deoxyribonucleic acid from microorganisms. J. Mol. Biol. 3 :208218.

27. Marmur, J., and P. Doty. 1961. Thermal renaturation of deoxyribonucleic acids. J. Mol. Biol. 3:585-594.

28. Meselson, M., F. W. Stahl, and J. Vinograd. 1957. Equilibrium sedimentation of macromolecules in density gradients. Proc Natl. Acad. Sci. U.S. 43:581-588.

29. Pinteric, L., and J. Taylor. 1962. The lowered drop method for the preparation of specimens of partially purified virus lysates for quantitative electron micrographic analysis. Virology 18:359-371.

30. Reich, E., A. J. Shatkin, and E. L. Tatum. 1961. Bacteriocidal action of mitomycin C. Biochim. Biophys. Acta 53: 132-149. 
31. Schildkraut, C. L., J. Marmur, and P. Doty. 1962. Determination of the base composition of deoxyribonucleic acid from its buoyant density in CsCl. J. Mol. Biol. 4:430-443.

32. Seaman, E., E. Tarmy, and J. Marmur. 1964. Inducible phages of Bacillus subtilis. Biochemistry. 3:607-613.

33. Stickler, D. J., R. G. Tucker, and D. Kay. 1965. Bacteriophagelike particles released from Bacillus subtilis after induction with hydrogen peroxide. Virology 26:142-145.

34. Studier, F. W. 1965. Sedimentation studies of the size and shape of DNA. J. Mol. Biol. 11:373-390.

35. Subbaiah, T. V., C. D. Goldthwaite, and J. Marmur. 1965. Nature of bacteriophages induced in Bacillus subtilis, $\mathrm{p}$. 435-436. In V. Bryson and H. J. Vogel (ed.), Symposium on evolving genes and proteins. Rutgers Institute of Microbiology, New Brunswick.

36. Svedberg, T., and K. O. Pederson. 1940. The ultracentrifuge. Oxford Univ. Press, Oxford, England.

37. Szybalski, W., and V. N. Iyer. 1964. Crosslinking of DNA by enzymatically or chemically activated mitomycins and porfiromycins, bifunctionally "alkylating" antibiotics. Federation Proc. 23:446-457.

38. Thomas, C. A., Jr. The arrangement of information in DNA molecules. J. Gen. Physiol. 49:143-169.

39. Tikhonenko, A. S., and I. A. Bespalova. 1966. Development of two phage forms in a cell of B. mycoides, p. 141. Intern Congr. Electron Microscopy, 6th Kyoto.

40. Tomizawa, J., and T. Ogawa. 1967. Effect of ultraviolet irradiation on bacteriophage lambda immunity. J. Mol. Biol. $23: 247-280$.

41. Wingert, L., and P. H. Von Hippel. 1968. The conformation dependent hydrolysis of DNA by micrococcal nuclease. Biochim. Biophys. Acta 157:114-126.

42. Yoshikawa, H. 1965. DNA synthesis during germination of Bacillus subtilis spores. Proc. Natl. Acad. Sci. U.S. 53: 1476-1483. 